\title{
Recombinant Interferon Beta
}

National Cancer Institute

\section{Source}

National Cancer Institute. Recombinant Interferon Beta. NCI Thesaurus. Code C495.

A recombinant protein which is chemically identical to or similar to endogenous interferon beta with antiviral and anti-tumor activities. Endogenous interferons beta are cytokines produced by nucleated cells (predominantly natural killer cells) upon exposure to live or inactivated virus, double-stranded RNA or bacterial products. These agents bind to specific cell-surface receptors, resulting in the transcription and translation of genes with an interferon-specific response element. The proteins so produced mediate many complex effects, including antiviral (the most important being inhibition of viral protein synthesis), antiproliferative and immune modulating effects. The recombinant therapeutic forms of interferon beta are interferon beta 1-a and interferon beta 1-b. ( $\mathrm{NCl05)}$ 